\title{
The Impact of the Organizational DNA on the Institutional Excellence of Alexandria Petroleum Companies through Improving Organizational Performance as a Mediating Variable
}

\author{
Rania Abd-Elazeem Mohamed Elsakaan, Ayman Ahmed Ragab, Alaa El-Gharbawy, \\ Abdel-Nasser Ghanem
}

Arab Academy for Science and Technology, Cairo, Egypt

Email: raniaelsakaan83@gmail.com

How to cite this paper: Elsakaan, R.A.-E.M., Ragab, A.A., El-Gharbawy, A. and Ghanem, A.-N. (2021) The Impact of the Organizational DNA on the Institutional Excellence of Alexandria Petroleum Companies through Improving Organizational Performance as a Mediating Variable. Open Access Library Journal, 8: e7691.

https://doi.org/10.4236/oalib.1107691

Received: June 24, 2021

Accepted: July 26, 2021

Published: July 29, 2021

Copyright $\odot 2021$ by author(s) and Open Access Library Inc.

This work is licensed under the Creative Commons Attribution International License (CC BY 4.0).

http://creativecommons.org/licenses/by/4.0/

(c) (i) Open Access

\begin{abstract}
The purpose of paper is to explore the role of the organizational performance as a mediating variable between organizational DNA and institutional excellence, also the paper aims to review the concept of organizational performance, and the different elements of organizational DNA and institutional excellence in service business organizations. In order to achieve the purposes of the study, researcher adopted a descriptive analytical method. The study develops a number of hypotheses and tests them. Of the (500) questionnaires that were distributed, (432) usable questionnaires were returned, a response rate of (86.4\%). Analyzing data was conducted using a set of statistical methods including a normality test along with Cronbach's alpha, standard deviation, confirmatory factor analysis, exploratory factor analysis, multiple and simple linear regression using SPSS-V26 and AMOS-V26. The study reached a set of results, the most important of which are: 1) There is a statistically impact at significant level $(\alpha \leq 0.05)$ of organizational DNA on institutional excellence through the organizational performance as a mediating variable in Alexandria petroleum companies; 2) There is a significant correlation between organizational performance and organizational DNA, also there is a significant correlation between organizational DNA and institutional excellence, and finally there is a significant correlation between organizational performance and institutional excellence. The study provided a set of recommendations including: 1) Organizations and institutions should be encouraged to establish excellence by instilling standards of excellence in daily
\end{abstract}


administrative procedures; 2) Encouraging organizations to pay attention to the components of organizational DNA (decision making rights, information, motivators, and structure) as they can form the organization's culture (decision making rights, information, motivators, and structure) which can help to identify organization strengths and weaknesses, and how to cope it.

\section{Subject Areas}

Organizational Behavior

\section{Keywords}

Organizational Performance, Organizational DNA, Institutional Excellence

\section{Introduction}

Business organizations work today in a global business environment where the only constant is discontinuous change. In such environment, organizations need transformations and changes (Soroush et al., 2014) [1]. Organizational development that involves a comprehensive standpoint in transformation management is an appropriate tool for today's managers; the managers that seek to be compatible with environmental changes and benefit from initiations and innovations in achieving their goals (Kaipa, 2005) [2].

One of the concepts that have been recently considered in management subjects is organizational DNA that describes organizations with a genetic aspect. organizational DNA is based on the principle that each organization has exclusive genetic characteristics like any living organisms and the characteristics are shown by the constructing, main and natural elements (DNA). Therefore, by combining management science with the reality of genetics and biology, effective ways could be made in developing the organizations in order to compate with continuous changes (Abdel-Raheem, Mohamed Saad (2019) [3].

A company's success or failure in the marketplace today is often not a matter of strategy; it is a function of execution. And execution is the product of organizational DNA. Organizational DNA is a technique or means used to pinpoint difficulties facing an organization and inhibiting its performance, along with ways to overcome such difficulties (Holoday, 2005) [4].

When companies experience problems in execution, they have only to look to their own organization structure, decision rights, motivators and information flows for answers. These form the substance of an organization's distinct identity and personality, the four "nucleotides" of its DNA, if you will. There were four elements which may call chromosomes that determine the organization gene which is decision rights, information, motivators, and structure (Neilson, 2006) [5].

The organizational DNA has an effective role in the identification of organizations and their leadership and management functions such as decisions, organizational structure, group work and communications, Identifying organizational 
DNA could help in improving innovative performance organizations (Saleh \& Ihsan, 2007) [6].

In the quest to improve performance, attention has been directed at organizational excellence to remain competitive through innovation and creativity (Al-Shibami et al., 2018) [7].

Organizational excellence was proposed to achieve an aim that has been established at a strategic level ensuring that objectives are met. Organizational excellence refers to the continuous attempt to meet or exceed the requirements and expectations of external and internal customers in the entire organizational processes, wherein all the employees work towards continuous improvement (AlMujaini et al., 2019) [8].

Organizational excellence facilitates the combination of the best organizational aspects by providing customer-oriented services, doing right the first time by preventing error, and mitigating inventory waste (Malek \& Kanji, 2009) [9].

Hence, this research aims to investigate the impact of the organizational DNA on the institutional excellence of Alexandria petroleum companies by improving organizational performance, also aims at identifying organizational DNA influence on innovative performance in local and international organizations in Egypt.

This paper is divided into nine sections, introduction, objectives of the research, research questions, research model, research hypothesis, research methodology, descriptive statistics, hypothesis testing results, results, recommendations and conclusion.

\section{Research Design}

\subsection{Objectives of the Research}

The objectives of the research are:

1) Investigate organizational DNA in Alexandria petroleum companies.

2) Reviewing the concepts of organizational DNA, organizational performance and institutional excellence.

3) Highlight the influence of organizational performance as a moderating variable of the relationship between organizational DNA and institutional excellence.

4) Formulate recommendations about how to enhancing organizational performance and how to gain institutional excellence, which may be benefit to practitioners and professionals.

\subsection{Research Questions}

The attempt of this study was to determine:

- Is there a statistical relationship with a significant impact between organizational DNA and the institutional excellence of this type of service organization?

- Do human resource management policies affect the organizational performance of Alexandria petroleum companies? 
- Does the organizational performance affect the institutional excellence of Alexandria petroleum companies?

- Is there an impact of organizational DNA on institutional excellence through the organizational performance as a mediating variable?

\subsection{Research Model}

The proposed comprehensive conceptual model is presented in diagram (1). Figure 1 shows that there is one independent variable for the study of organizational DNA. There is one dependent variable institutional excellence and a mediating variable is organizational performance.

\subsection{Research Hypothesis}

- There is a statistically significant effect of organizational DNA on organizational performance.

- There is a statistically significant effect of organizational DNA on institutional excellence.

- There is a statistically significant effect of the organizational performance on institutional excellence.

- There is a statistically significant effect of organizational DNA on institutional excellence with organizational performance as a mediating variable.

\section{Research Methodology}

The study adopted a descriptive analytical method, the questionnaire was study's main tool for collecting data; where (500) questionnaires were distributed, and (432) questionnaires were retrieved for analysis, the rate was (86.4\%) of the distributed questionnaires. Analyzing data was conducted using a set of statistical methods including a normality test, along with Cronbach's alpha, means, standard deviation, confirmatory factor analysis, exploratory factor analysis, multiple and simple linear regression using SPSS-V26 and AMOS-V26.
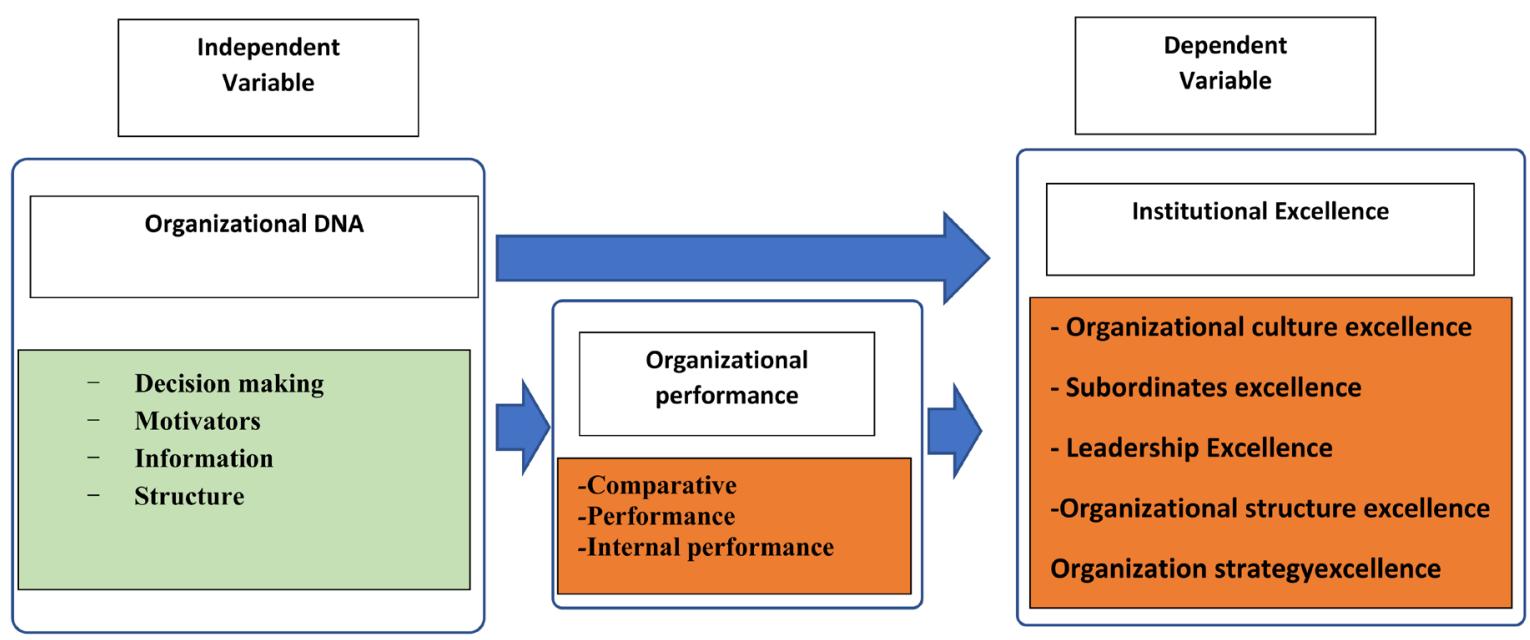

Figure 1. Shows the research model of this study. (Source: by researcher depending on previous studies). 


\subsection{Study Tool}

The study relied on the questionnaire as the performance of the main study. A questionnaire was prepared on "the impact of the organizational performance as a mediating variable between organizational DNA and institutional excellence" applied study Alexandria petroleum companies.

The questionnaire consists of:

1) Part 1: personal data.

2) Part 2: variables dimensions and items.

Questionnaire Building steps:

Study questionnaire to be in the final form as introduced, researcher had the following steps:

- Review the literature and previous studies related to the subject of the study, to have the structure in building the questionnaire and formulating its paragraphs.

- The researcher consulted a number of Egyptian university professors and administrative supervisors in the field.

- Determining the main dimensions of the questionnaire according to the study variables.

- Determine the main items for each dimension included in the questionnaire.

- Determine items that fall under each field.

- Presenting the questionnaire to the supervisor for discussion and comments.

- The questionnaire was designed in its initial form and it consisted of three main dimensions and (74) items.

- The questionnaire was judged by (5) arbitrators with experience in academic and professional field.

- According to arbitrators' opinions, some items of the questionnaire were modified in terms of deletion, addition and modification.

- In order for the questionnaire to settle in its final form on (72) items,

Table 1 shows the sources of the questionnaire items that were developed from previous studies.

\subsection{Pilot Study}

In order to testing questionnaire validity and reliability, the researcher distributed a survey sample of (34) questionnaires.

To assess the reliability of the data, Cronbach's alpha test was conducted. Table 4 shows the reliability results for organizational DNA, Organizational Performance and institutional excellence. All items had alphas above 0.60 and were therefore excellent, according to Langdridge's criteria. (Wheelen, \& Hunger, 2004) [13].

\subsection{Evaluating Reliability}

Table 2 shows the reliability of organizational DNA and OP. 
Table 1. Questionnaire items.

\begin{tabular}{|c|c|c|c|c|c|}
\hline \multicolumn{2}{|c|}{ Variable } & Dimensions & $\begin{array}{l}\text { No of } \\
\text { Items }\end{array}$ & Items & Source \\
\hline \multirow{4}{*}{ Independent } & \multirow{4}{*}{$\begin{array}{c}\text { Organizational } \\
\text { DNA }\end{array}$} & Decision making & 9 Items & $1: 9$ & \multirow{4}{*}{$\begin{array}{c}\text { Neilson } \\
\text { et al., } \\
2006[10]\end{array}$} \\
\hline & & Motivators & 10 Items & $10: 19$ & \\
\hline & & Information & 8 Items & $20: 27$ & \\
\hline & & Structure & 10 Items & $28: 37$ & \\
\hline \multirow{5}{*}{ Dependent } & \multirow{5}{*}{$\begin{array}{l}\text { Institutional } \\
\text { Excellence }\end{array}$} & $\begin{array}{c}\text { Organizational } \\
\text { culture excellence }\end{array}$ & 5 Items & $38: 42$ & \multirow{5}{*}{$\begin{array}{l}\text { AL-Amri } \\
2017[11]\end{array}$} \\
\hline & & Subordinates excellence & 5 Items & $43: 47$ & \\
\hline & & & 5 Items & $48: 52$ & \\
\hline & & $\begin{array}{c}\text { Organizational } \\
\text { structure excellence }\end{array}$ & 5 Items & $53: 57$ & \\
\hline & & $\begin{array}{c}\text { Organization } \\
\text { strategy excellence }\end{array}$ & 5 Items & $58: 62$ & \\
\hline \multirow{2}{*}{ Mediator } & Organizational & Comparative Performance & 5 Items & $63: 67$ & \multirow{2}{*}{$\begin{array}{c}\text { Nafei, } \\
2015 \text { [12] }\end{array}$} \\
\hline & performance & Internal performance & 5 Items & $67: 72$ & \\
\hline
\end{tabular}

Table 2. Reliability of organizational DNA and OP.

\begin{tabular}{|c|c|c|c|c|c|}
\hline & riable & Dimensions & $\begin{array}{l}\text { No of } \\
\text { Items }\end{array}$ & Items & $\begin{array}{c}\text { Cronbach } \\
\text { Alpha } \\
\text { coefficient }\end{array}$ \\
\hline \multirow{5}{*}{ Independent } & \multirow{5}{*}{$\begin{array}{l}\text { Organizational } \\
\text { DNA }\end{array}$} & Decision making & 9 Items & $1: 9$ & 0.619 \\
\hline & & Motivators & 10 Item & $10: 19$ & 0.604 \\
\hline & & Information & 8 Items & $20: 27$ & 0.637 \\
\hline & & Structure & 10 Item & $28: 37$ & 0.614 \\
\hline & & \multicolumn{3}{|c|}{ Total Measurement } & 0.819 \\
\hline \multirow{6}{*}{ Dependent } & \multirow{6}{*}{$\begin{array}{l}\text { Institutional } \\
\text { Excellence }\end{array}$} & $\begin{array}{c}\text { Organizational } \\
\text { culture excellence }\end{array}$ & 5 Items & $38: 42$ & 0.768 \\
\hline & & Subordinates excellence & 5 Items & $43: 47$ & 0.706 \\
\hline & & Leadership Excellence & 5 Items & $48: 52$ & 0.672 \\
\hline & & $\begin{array}{c}\text { Organizational } \\
\text { structure excellence }\end{array}$ & 5 Items & $53: 57$ & 0.611 \\
\hline & & $\begin{array}{c}\text { Organization } \\
\text { strategy excellence }\end{array}$ & 5 Items & $58: 62$ & 0.694 \\
\hline & & Total Measur & ment & & 0.878 \\
\hline \multirow{4}{*}{ Mediator } & Organizational & Comparative Performance & 5 Items & $63: 67$ & 0.634 \\
\hline & performance & Internal performance & 5 Items & $67: 72$ & 0.778 \\
\hline & & \multicolumn{3}{|c|}{ Total Measurement } & 0.756 \\
\hline & & \multicolumn{3}{|c|}{ Total Measurement } & 0.926 \\
\hline
\end{tabular}




\subsection{Evaluating Validity}

In this research, all scales for measuring study variables constructs have content validity since the development of these measurement items was based mainly on an extensive review of the literature, all questionnaire items judged by arbitrators with experience in academic and professional field.

\subsection{Descriptive Statistics}

Before testing the hypotheses and research questions, descriptive statistics were performed to find out means and standard deviations of organizational DNA, Organizational Performance and institutional excellence.

According to Table 3, the different facets of Organizational DNA are examined. Most respondents identified the presence of Structure $(\mathrm{M}=4.46, \mathrm{SD}=$ $0.27)$. This was followed by Information $(\mathrm{M}=4.42, \mathrm{SD}=0.26)$, Decision making $(\mathrm{M}=4.38, \mathrm{SD}=0.36)$, Motivators $(\mathrm{M}=3.86, \mathrm{SD}=0.36)$ and the total measurement for Organizational DNA ( $\mathrm{M}=4.33, \mathrm{SD}=0.275)$.

The different facets of Institutional Excellence are examined. Most respondents identified the presence of Leadership Excellence $(M=4.49, S D=26)$. This was followed by Subordinates excellence $(\mathrm{M}=4.48, \mathrm{SD}=0.28)$, Organizational structure excellence $(\mathrm{M}=4.40, \mathrm{SD}=0.37)$, Organization strategy excellence $(M=4.37, S D=0.54)$, Organizational culture excellence $(M=4.32$, $\mathrm{SD}=0.51)$ and the total measurement for Institutional Excellence $(\mathrm{M}=4.40$, $\mathrm{SD}=0.19)$.

Table 3. The mean and standard deviations of variables.

\begin{tabular}{|c|c|c|c|c|}
\hline \multicolumn{2}{|c|}{ Variables } & Dimensions & Mean & $\begin{array}{l}\text { Standard } \\
\text { Deviations }\end{array}$ \\
\hline \multirow{5}{*}{ Independent } & \multirow{5}{*}{$\begin{array}{c}\text { Organizational } \\
\text { DNA }\end{array}$} & Decision making & 4.38 & 0.36 \\
\hline & & Motivators & 3.86 & 0.35 \\
\hline & & Information & 4.42 & 0.26 \\
\hline & & Structure & 4.46 & 0.27 \\
\hline & & $\begin{array}{l}\text { Total measurement of } \\
\text { Organizational DNA }\end{array}$ & 4.33 & 0.275 \\
\hline \multirow{6}{*}{ Dependent } & \multirow{6}{*}{$\begin{array}{l}\text { Institutional } \\
\text { Excellence }\end{array}$} & Organizational culture excellence & 4.32 & 0.51 \\
\hline & & Subordinates excellence & 4.48 & 0.28 \\
\hline & & Leadership Excellence & 4.49 & 0.26 \\
\hline & & Organizational structure excellence & 4.40 & 0.375 \\
\hline & & Organization strategy excellence & 4.37 & 0.54 \\
\hline & & $\begin{array}{l}\text { Total measurement of } \\
\text { Institutional Excellence }\end{array}$ & 4.40 & 0.19 \\
\hline \multirow{3}{*}{ Mediator } & Organizational & Comparative Performance & 4.40 & 0.4 \\
\hline & performance & Internal performance & 4.30 & 0.43 \\
\hline & & $\begin{array}{c}\text { Total measurement of } \\
\text { Organizational Performance }\end{array}$ & 4.45 & 0.18 \\
\hline
\end{tabular}


The different facets of Organizational performance are examined. Most respondents identified the presence of Comparative Performance $(\mathrm{M}=4.46, \mathrm{SD}=$ $275)$. This was followed by Internal Performance $(M=4.40, S D=0.4)$ and the total measurement for Organizational performance $(\mathrm{M}=4.45, \mathrm{SD}=0.18)$.

\section{Hypothesis Testing Results}

\subsection{First Hypothesis Test}

To test the first hypothesis, the null hypothesis was developed which is that there is no significant statistical effect of organizational DNA, on the organizational performance of Alexandria petroleum companies, and to verify the validity of the hypothesis, the simple regression test was used between organizational DNA as an independent variable, and the organizational performance is a dependent variable, Table 2 shows the results as follows.

It is evident from Table 4 that the statistical value $(\mathrm{T})$ is (2.23) with a statistical significance level less than $5 \%$ ( $\mathrm{p} \leq 0.05$ ), we reject the null hypothesis, which indicates that there is a statistically significant impact of organizational DNA on the organizational performance, and accordingly there is a statistically significance of organizational DNA on the organizational performance.

Regression equation is:

$$
y=\propto+B X
$$

organizational performance $=4.076+0.077$ organizational DNA.

\subsection{Second Hypothesis Test}

To test the second hypothesis, the null hypothesis was developed which is that there is no significant statistical effect of organizational DNA on the institutional excellence of Alexandria petroleum companies.

Table 5 shows the results as follows:

Table 4. Simple regression analysis results for organizational DNA and organizational performance.

\begin{tabular}{cccc}
\hline & B & T & Sig \\
\hline Constant & 4.076 & 27.19 & 0.000 \\
Organizational DNA & 0.077 & 2.23 & 0.026 \\
Correlation Coefficient $\mathbf{R}$ & 0.107 & Determination Coefficient $\mathbf{R}^{2}$ & 0.011
\end{tabular}

Table 5. Simple regression analysis results for organizational DNA and institutional excellence.

\begin{tabular}{cccc}
\hline & B & T & Sig \\
\hline Constant & 4.17 & 29.809 & 0.000 \\
Organizational DNA & 0.066 & 2.037 & 0.04 \\
Correlation Coefficient R & 0.09 & Determination Coefficient $\mathbf{R}^{2}$ & 0.01 \\
\hline
\end{tabular}


Regression equation is:

$$
y=\propto+B X
$$

institutional excellence $=4.17+0.066$ organizational DNA.

It is evident from Table 4 that the statistical value (T) is (2.037) with a statistical significance level less than $5 \%$, which indicates that there is a statistically significance impact of organizational DNA on institutional excellence.

\subsection{Third Hypothesis Test}

To test the third hypothesis, the null hypothesis was developed which is that there is no significant statistical effect of organizational performance on the institutional excellence of Alexandria petroleum companies.

Table 6 shows the results as follows:

Regression equation is:

$$
y=\propto+B X
$$

institutional excellence $=3.19+0.273$ organizational performance.

It is evident from Table 4 that the statistical value $(T)$ is (5.46) with a statistical significance level less than $5 \%$, which indicates that there is a statistically significance impact of organizational performance on institutional excellence.

\subsection{Fourth Hypothesis}

To test the third main hypothesis, the null hypothesis was developed, which is the absence of a statistically significant relationship between organizational DNA and institutional excellence through the organizational performance as a mediating variable.

And to verify the validity of the hypothesis and study the extent of a complete or partial relationship, the Path Analysis test was used, using the Amos 26, program and Figure 2 and Table 7 show the results:

1) Observed Exogenous Variables: The independent variable includes organizational DNA.

Table 6. Simple regression Analysis results for organizational performance and institutional excellence.

\begin{tabular}{cccc}
\hline & B & T & Sig \\
\hline Constant & 3.19 & 14.319 & 0.000 \\
Organizational Performance & 0.273 & 5.46 & 0.000 \\
Correlation Coefficient $\mathbf{R}$ & 0.255 & Determination Coefficient $\mathbf{R}^{2}$ & 0.06 \\
\hline
\end{tabular}

Table 7. Variables path estimates.

\begin{tabular}{ccccc}
\hline Effect Direction & Estimate & S.E & C.R & Sig \\
\hline Organizational DNA on Organizational Performance & 0.07 & 0.038 & 2.040 & 0.000 \\
Organizational Performance on the institutional excellence & 0.264 & 0.035 & 5.290 & 0.000 \\
Organizational DNA on the institutional excellence & 0.060 & 0.039 & 1.776 & 0.063
\end{tabular}




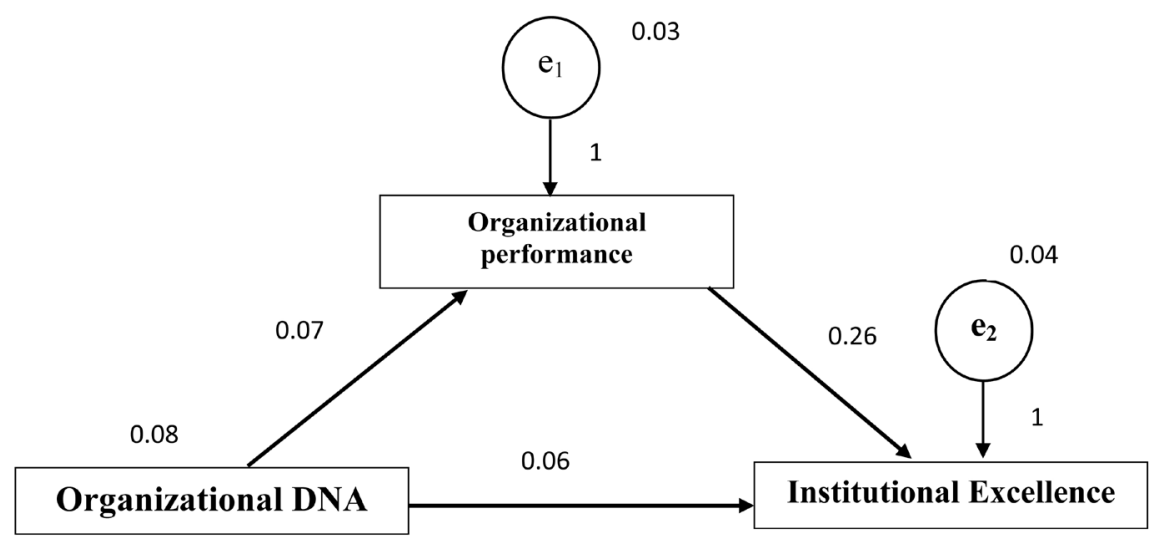

Figure 2. Variable mediating paths.

2) Observed Endogenous Variables: The dependent variable includes institutional excellence, and the mediating variable includes the organizational performance.

3) Unobserved Exogenous Variables: Measurement errors of the dimensions of the dependent variable include institutional excellence, and the mediating variable, organizational performance.

From the previous table and figure, it is clear that at a level of significance 0.05 , there is a statistically significant effect of organizational DNA path on the organizational performance with a factor of 0.07 and the organizational performance Path on institutional excellence with an impact factor of 0.26 , as the value of the level of significance for both path are 0.000 , which is less than 0.05 While there is no statistically significant impact of the organizational DNA path on institutional excellence, as the value of the level of significance is equivalent to 0.06, (greater than 0.05).

Table 8 shows the following:

Chi-square $(X 2)$ : tests the null hypothesis of this test is, the model fits the model is better when it has a small value, whereas this model value is 0.000 , model is fit.

Goodness of Fit Index (GFI): purpose of computing GFI in the case of maximum likelihood estimation, GFI is less than or equal to 1 . Whereas model (GFI) amounted 1 , it indicates a perfect fit.

The Comparative Fit Index (CFI): parameter estimate for the model being evaluated; CFI is truncated to fall in the range from 0 to 1 . CFI values close to 1 indicate a very good fit. Whereas this model value is 1 , model is fit.

The square root of the mean squares of remainder (RMR): It is an indicator of the estimated amount, and the model is better when it has a small value, whereas this model value is 1 , model is fit.

Root Mean Square Error of Approximation (RMSEA): Independent model value is 0.160 , the value of the RMSEA of about 0.05 or less would indicate a close fit of the model in relation to the degrees of freedom, but for the independent model, it accepted according to Independent model. 
Table 8. Model fit index.

\begin{tabular}{cc}
\hline Default Model & Index \\
\hline GFI & 1 \\
CFI & 1 \\
RMR & 0.00 \\
RMSEA & 0.160 \\
Chi-Square & 0 \\
\hline
\end{tabular}

Based on the previous results and after checking the model test and all the criteria for judging model goodness, and accordingly, the relationship to the mediating variable, which is the organizational performance, is a holistic relationship and not a partial one, as there is no significance for the relationship between organizational DNA on the institutional excellence of the existence of the organizational performance, which means that the organizational performance A necessary condition for the impact of organizational DNA on institutional excellence.

\section{Results}

- There is positive correlation between organizational DNA and organization performance, the higher the level of the total organizational DNA, the higher the level of the organization performance.

- There is a statistically significant impact of organizational DNA on the organizational performance.

- There is a statistically significant impact of the dimensions of organizational DNA (decision making rights, information, motivators, and structure) on the organizational performance.

- There is a statistically significant impact of organizational DNA on institutional excellence.

- There is a statistically significant impact of organizational DNA on institutional excellence through organizational performance as a mediator variable.

\section{Recommendations}

- The necessity to pay more attention to the dimensions of organizational DNA as of a key source for organizations to enhance the competitive advantage which is of prime significance for organization performance.

- Organizations and institutions should be encouraged to establish excellence by instilling standards of excellence in daily administrative, technical and financial procedures at all strategic and operational levels so that these standards become rooted in the institutional structure.

- It should be giving more importance to qualifying top management team in institutions to taking into consideration the factors of Organizational DNA as well as the exploitation of competitive capabilities and advantages in evaluating their work and implementing their programs. 
- It is very important to focus on the organizational DNA dimensions; the decision-making, information, organizational structure, and motivation.

- Encouraging all organizations to pay attention to the components of organizational DNA as part of the organization's culture (decision making rights, information, motivators, and structure) and to clarify its importance to all employees because it helps to identify organization strengths and weaknesses, and how to treat them and helps improve the behavior and performance of human resources in the organization.

- Spreading the concept of organizational DNA and its components between the employees is very important, to show its role in the identification of the organizations identity by creativity and innovation as crucial elements of organization's competitivity and its permanence.

\section{Conclusions}

When companies face problems in execution, they have only to look to their own organization structure, motivators, decision rights and information flows for solutions. These form the substance of an organization's distinct identity and personality of the four "nucleotides" of its DNA. Organizational DNA plays a very great role in building and forming organization's culture which may participate in achieving competitive advantage and enhancing organization performance.

The components of organizational DNA as part of the organization's culture (decision making rights, information, motivators, and structure) are very important to all employees because it helps to identify organization strengths and weaknesses, and how to treat them and helps improve the behavior and performance of human resources in the organization. The higher the level of the total organizational DNA, the higher the level of the organizational performance. The higher the degree of (decision rights, information, organizational structure and motivators), the greater the organization performance and institutional excellence in the local organization. Each of the four components of organizational DNA affects the increase of the institutional excellence of the local organization. Therefore, it's necessity to pay more attention to the dimensions of organizational DNA as a key source for organizations to enhance the competitive advantage which is of prime significance for organization performance.

\section{Conflicts of Interest}

The authors declare no conflicts of interest.

\section{References}

[1] Soroush, S., Mohammad pouri, M., Poorfarahmand, B. and Esfahani, D. (2014) Studying of Organizational DNA in Esfahan Province Sport and Youth of Fiches. International Journal of Human Resource Studies, 4. https://doi.org/10.5296/ijhrs.v4i3.5930

[2] Kaipa, P. and Milua, T. (2005) Mapping the Organizational DNA: A Living System 
Approach to Organization Transformation. http://www.prasadkaipa.com/

[3] EL Din Abdel-Raheem, A.B. and Saad, M. (2019) Organizational Personality as a Moderating Variable of the Relationship between Organizational DNA and Innovative Performance. Journal of Business and Management Sciences, 7, 131-139. http://pubs.sciepub.com/jbms/7/3/4

[4] Holoday, R. (2005) Simple Rules: Organizational DNA. Human System Dynamics, 37, 1-10.

[5] David, G.K. and Neilson, G. (2019) Organizational to Executive: It's in the DNA. Journal of Business and Management Sciences, 7, 131-139.

[6] Rashid, S. and Challab, I. (2007) The Influence of Organizational DNA on Innovation Performance: An Empirical Study in a Sample of Iraqi Industrial Organizations. AL-Qadisiyah Journal for Administrative and Economic Sciences, 9, 9-22.

[7] Mohamed, M., Khalifa, G., Nusari, M., Ameen, A., Al-Shibami, A. and Abuelhassan, A. (2018) Effect of Organizational Excellence and Employee Performance on Organizational Productivity within Healthcare Sector in the UAE. Journal of Engineering and Applied Sciences, 13, 6199-6210. https://doi.org/10.36478/jeasci.2018.6199.6210

[8] AlMujaini, H., Abudaqa, A. and Hilmi, M. (2019) The Influencing Factors of Organizational Excellence on Corporate Foresight: Artificial Intelligence as Moderator. International Journal of Recent Technology and Engineering (IJRTE), 8, 2277-3878. https://doi.org/10.35940/ijrte.B2439.078219

[9] Malek, A.B.D.U.L. and Kanji, G.O.P.A.L. (2009) Organizational Excellence in Malaysian Higher Education Institutions. Sinergierapporti di ricerca n. 9.

[10] Neilson, G., Pasternack, B. and Mendes, D. (2005) The Four Bases of Organizational DNA. http://www.boozallen.com

[11] AL-Amri, M.S. (2017) The Impact of Organizational Change on Organizational Excellence: An Applied Field Study on Private Sector in Saudi Arabia. College of Business Administration King Saud University.

[12] Nafei, W. (2014) The Role of Organizational DNA in Improving Organizational Performance: A Study on the Industrial Companies in Egypt. International Business Research, 8. https://doi.org/10.5539/ibr.v8n1p117

[13] Wheelen, T.L. and Hunger, J.D. (2004) Strategic Management and Business Policy: Concepts. (th $^{\text {th }}$ Edition, Pearson Education, Inc., Upper Saddle River. 